\title{
NEW FROM CALIFORNIA
}

\section{Man Is Wolf to Man}

Surviving the Gulag

Janusz Bardach and Kathleen Gleeson

Foreword by Adam Hochschild

"This book provokes memories and emotions long-forgotten of the time I lived myself under the Communist regime. I found myself a diligent reader filling in many mental footnotes of my experiences during this era."-Czeslaw Milosz $\$ 29.95$ cloth, illustrated

\section{Stalin's Forgotten Zion}

Birobidzhan and the Making of a Soviet Jewish Homeland An Illustrated History, 1928-1996

Robert Weinberg Illustrations edited by Bradley Berman With an Introduction by Zvi Gitelman Robert Weinberg and Bradley Berman's carefully documented and extensively illustrated book explores the Soviet government's failed experiment to create a socialist Jewish homeland. Published in association with The Judah L. Magnes Museum $\$ 55.00$ cloth, $\$ 24.95$ paper, illustrated

\section{Insider/Outsider}

American Jews and Multiculturalism

David Biale, Michael Galchinsky, and Susannah Heschel, Editors

"Invaluable reading for anyone interested in multiculturalism."-Julius Lester, author of Lovesong "Insider/Outsider provides insight into the situation not only of American Jews but also of all hyphenated American identities." - Stephen Greenblatt $\$ 45.00$ cloth, $\$ 16.95$ paper

At bookstores or order 1-800-822-6657

\section{University of California Press} www.ucpress.edu

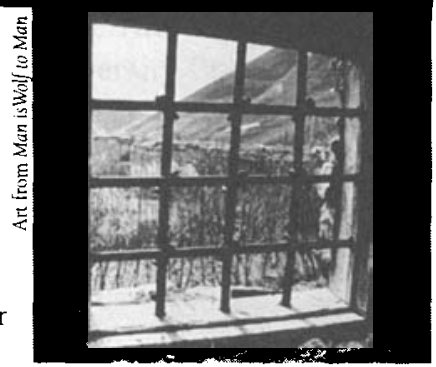

\section{Rubber Bullets}

Power and Conscience in Modern Israel Yaron Ezrahi New in paperback - "One of the most original and stimulating books about Israel and Zionism for a long time. . . Ezrahi describes brilliantly how Zionism came to devalue the Western ideals of individual happiness and self-realization."

-New York Times Book Review 1997 National Jewish Book Award, $\$ 16.95$ paper

\section{Blackface, White Noise}

Jewish Immigrants in the Hollywood Melting Pot Michael Rogin New in paperback"Energetic, even revelatory. ... [Rogin has] a robust appetite for cultural connections." - The Nation A Centennial Book $\$ 17.95$ paper, illustrated 


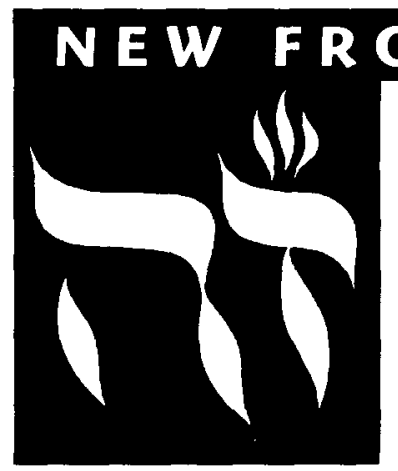

Jewish Icons

Art and Society in

Modern Europe

Richard I. Cohen

"Cohen's analysis of images of Jews advances swiffly beyond the history of stereotypes in favor of a complexity of mutual perception, and his depiction of images by Jews challenges the standard assumption of the antivisuality of Jewish culture."

-Michael P. Steinberg, Cornell University

$\$ 50.00$ cloch, illustrated

\section{The Song of Songs}

A New Translation

With an Introduction and Commentary by Ariel Bloch and Chana Bloch Afterword by Robert Alter "[This translation] has a crisp energy that mirrors the poem's springtime mood, and a phrasing that captures the impulsiveness and the delight of the lovers."

-New York Review of Books $\$ 17.95$ paper

\section{Black Fire on White Fire}

An Essay on Jewish Hermeneutics, from Midrash to Kabbalah

Betty Rojtman

Translated by Steven Rendall

Preface by Moshe Idel

"This illuminating book brings together in an extraordinary way contemporary linguistic theory and Jewish hermeneutics."

-J. Hillis Miller, author of Topographies Contraversions, $\$ 45.00$ cloth, $\$ 17.95$ paper, illustrated

\section{The Dispersion of Egyptian Jewry}

Culture, Politics, and the Formation of a Modern Diaspora

Joel Beinin

"The best sort of historical revisionism-sophisticated but unobtrusive in its use of theory, consistently contextual in its assessment of sources and texts, open-ended and suggestive of broader implications in its conclusions."

-James Jankowski, coauthor of Redefining the Egyptian Nation, 1930-1945 Contraversions, $\$ 45.00$ cloth, illustrated

\section{Heritage and Hellenism}

\section{The Reinvention of Jewish Tradition}

\section{Erich S. Gruen}

"This excellent volume focuses on the writings of Jews in Greek. .. A book of broad scholarly interest to both scholars and everyone interested in the development of Judaism."

-Robert Doran, Amherst College Hellenistic Culture and Society, $\$ 38.00$ cloth

At bookstores or order 1-800-822-6657

\section{University of California Press www.ucpress.edu}

